\title{
FAKTOR-FAKTOR YANG MEMPENGARUHI KEJADIAN DISFUNGSI SEKSUAL PADA WANITA MENOPAUSE DI WILAYAH KERJA PUSKESMAS TAMBUSAI
}

\author{
Masdi Janiarli ${ }^{1}$, Cicilia Melinda ${ }^{2}$ \\ Universitas Pasir Pengaraian \\ Email korespondensi : masdijaniarli@gmail.com
}

\begin{abstract}
Abstrak
Disfungsi seksual merupakan ketidakmampuan untuk menikmati secara penuh hubungan seksual yang disebabkan karena masalah biologis, psikologis, dan interpersonal. Disfungsi seksual seringkali terjadi dalam kehidupan rumah tangga, apabila tidak segera diobati bisa menyebabkan keretakan dalam rumah tangga. Salah satu faktor penyebab keretakan dalam rumah tangga, sekitar $12 \%$ disebabkan masalah seks. Sedangkan masalah seks yang dialami suami - istri yaitu lebih dari 66\%. Hal ini disebabkan karena banyaknya pasangan yang tidak mempermasalahkannya atau mampu meredamnya, hingga tidak merasa perlu meributkannya. Tujuan penelitian untuk mempelajari dan menjelaskan gambaran kejadian disfungsi seksual dan faktor dominan yang mempengaruhi kejadian disfungsi seksual pada wanita menopause. Jenis pendekatan kuantitatif dengan rancangan cross sectional. Populasi sebanyak 198 wanita yang sudah menopause dan mempunyai pasangan. Sampel sebanyak 76 orang dipilih dengan teknik proportional random sampling. Pengumpulan data wawancara langsung menggunakan kuesioner FSFI melalui kunjungan rumah dan melakukan pengukuran tinggi badan menggunakan stadio meter dan berat badan menggunakan timbangan digital. Uji statistik menggunakan Chi Square dan Regresi Logistik Ganda. Hasil penelitian menunjukkan semua variabel berhubungan dengan kejadian disfungsi seksual dan variabel dominan adalah lama menopause dengan $\mathrm{OR}=$ 28. Disarankan meningkatkan pelayanan tentang disfungsi seksual pada pasangan menopause yang dikaitkan dengan riwayat penyakit sistemik dan memfasilitasi ahli yang relevan dengan disfungsi seksual
\end{abstract}

Kata kunci: Disfungsi Seksual, Menopause, Lama Menopause.

\begin{abstract}
Sexual dysfunction is a decrease of libido or sexual desiSre in a person within sexual intercourse due to biological problems, psychological, and interpersonal factors. Sexual dysfunction often happens in household life, if sexual dysfunction often occurs in household life, if it is not promptly treated, it can lead to crack the household. One of the factors can cause the cracks in the household life, it is approximately $12 \%$ due to the problems of sex. While sexual problems that experienced by husbands and wives of more than $66 \%$. This is because many couples are not disputed or it is able to mute, so it does not need get into fuss. This research aimed at identifying and describing the incidence of sexual dysfunction and the dominant factor affecting the incidence of sexual dysfunction in menopausal women. The approach of this research employed quantitative approach using cross sectional design. The population is 198 menopausal women and have spouses. The samples are 76 respondents selected using proportional random sampling technique. The data collection technique in this research used the direct interview FSFI questionnaires through home visits and conducted measurements of height using stadio meter and weight using digital scales. Statistical test in this research used Chi Square test and Multiple Logistic Regression. The results of this research showed that all variables are related to the incidence of sexual dysfunction, and the dominant variable is lenght of menopause, determined by $O R=28$. This study suggests to increase service about sexual dysfunction upon the menopausal spouse that are related to the history of systematic diseases and facilitating to consult with experts who concern with sexual dysfunction.
\end{abstract}

Keywords: Sexual Dysfunction, Menopause, Length of Menopause.

\section{Pendahuluan}

Banyak orang yang tidak menyadari bahwa kehidupan seksual akan mempengaruhi kualitas hidup seseorang. Salah satu aspek penting untuk menentukan kualitas hidup seseorang adalah kehidupan seksual. Karena

\footnotetext{
${ }^{1}$ Dosen Universitas Pasir Pangaraian

${ }^{2}$ Dosen Universitas Pasir Pangaraian
} 
aktifitas seksual merupakan salah satu aspek untuk menilai kualitas hidup seseorang ${ }^{1}$.

Aktivitas seksual merupakan suatu kebutuhan biologis bagi manusia untuk mendapatkan keturunan. Dalam kehidupan rumah tangga, masalah seksual seringkali mengalami gangguan karena salah satu pihak (suami atau isteri) atau bahkan keduanya. Jika tidak segera diobati, masalah tersebut bisa menyebabkan keretakan dalam rumah tangga ${ }^{2,3}$.

Dari sekian banyak faktor penyebab terjadinya keretakan dalam rumah tangga, sekitar 12\% disebabkan masalah seks. Angka tersebut terhitung kecil, tetapi tidak boleh dianggap remeh karena masalah seks yang dialami suami - istri sebenarnya cukup banyak yaitu lebih dari 66\%. Mencoloknya perbedaan angka keretakan dalam rumah tangga dengan masalah seks disebabkan karena banyaknya pasangan yang tidak mempermasalahkannya atau mampu meredamnya, hingga tidak merasa perlu meributkannya ${ }^{4}$.

Pada laki - laki maupun wanita yang mau melakukan pengobatan kepada dokter hanya 9 $\%$. Bahkan di Korea hanya $2 \%$ laki - laki maupun wanita yang membicarakan keluhan seksualnya kepada dokter ${ }^{5}$. Sejauh ini penulis belum menemukan kelompok umur yang melakukan pengobatan kepada dokter terkait dengan kejadian disfungsi seksual.

Hal ini disebabkan karena merasa malu dengan masalah yang dianggap paling rahasia, tidak tahu kemana harus mengungkapkan, tidak mengerti bahwa gangguan fungsi seksual itu suatu penyakit, dan gangguan tersebut bisa diatasi ${ }^{6}$. Selain itu hambatan sosial budaya juga menyebabkan masalah seksual dianggap tabu untuk dibicarakan oleh setiap orang ${ }^{7}$.

Secara umum masalah seksual pada pria maupun wanita, dibedakan dalam tiga kelompok, yaitu keluhan seksual, disfungsi seksual, dan penyimpangan seksual. Namun dari ketiganya, yang sering menjadi persoalan adalah disfungsi seksual ${ }^{8}$.

Disfungsi seksual secara luas adalah ketidakmampuan untuk menikmati secara penuh hubungan seksual dengan pasangannya. Gangguan ini terjadi karena berbagai hal, baik secara fisik maupun psikologis, dan memberikan efek yang kurang baik bagi keharmonisan rumah tangga ${ }^{9}$.

Penelitian epidemiologis secara konsisten menemukan bahwa disfungsi seksual merupakan gangguan yang lebih sering terjadi pada wanita dibanding laki - laki dengan prevalensi $40 \%$ pada laki - laki dan 50\% pada wanita yang berada dalam periode perimenopause dan postmenopause ${ }^{10}$.

Data resmi mengenai jumlah penderita disfungsi seksual di Indonesia belum ada, namun diperkirakan pada tahun 2004, 15\% penduduk usia > 40 tahun mengalami disfungsi seksual. Hal ini menunjukkan bahwa sebenarnya masalah disfungsi seksual sangat luas dalam masyarakat, namun hanya sedikit yang merasa memerlukan penanganan ${ }^{11}$.

Penelitian yang dilakukan di dusun Tegal Sari desa Jabon kecamatan Mojoanyar 
kabupaten Mojokerto menyebutkan bahwa sebagian besar wanita yang sudah menopause memiliki persepsi negatif tentang aktivitas seksual pada saat menopause yaitu sebesar 59\%. Hal ini disebabkan karena mereka masih menganggap hubungan seksual merupakan kewajiban seorang istri untuk memenuhi kebutuhan seksual suami agar bisa menjaga keharmonisan rumah tangga ${ }^{12}$.

Tujuan penelitian untuk mengetahui hubungan variabel independen dengan variabel dependen dan variabel dominan terhadap kejadian disfungsi seksual pada wanita menopause.

\section{Metode}

Jenis penelitan kuantitatif menggunakan survey analitik dengan desain Cross Sectional. Populasi pada penelitian ini adalah semua wanita yang sudah menopause dan mempunyai pasangan sebanyak 198 orang. Pengambilan sampel menggunakan teknik proportional random sampling sebanyak 76 orang.

Teknik pengumpulan data wawancara langsung menggunakan kuesioner FSFI yang terstruktur dengan 19 pertanyaan terdiri dari enam domain fungsi seksual yaitu minat, birahi, orgasme, lubrikasi, kepuasan, dan rasa nyeri dan melakukan pemeriksaan berat badan dan tinggi badan menggunakan timbangan digital dan stadio meter.

\section{Hasil dan Pembahasan}

\section{Analisis Univariat}

\begin{tabular}{|c|c|c|}
\hline Distribusi responden & Jumlah & Persentase \\
\hline \multicolumn{3}{|l|}{ Kejadian Disfungsi } \\
\hline Disfungsi seksual (skor $\leq 26,5$ ) & 50 & $65,8 \%$ \\
\hline Tidak disfungsi seksual (skor $>26,5$ ) & 26 & $34,2 \%$ \\
\hline \multicolumn{3}{|l|}{ Domain Disfungsi } \\
\hline Hasrat seksual & 14 & $28,0 \%$ \\
\hline Rangsangan seksual & 12 & $24,0 \%$ \\
\hline Lubrikasi vagina & 10 & $20,0 \%$ \\
\hline Orgasme & 5 & $10,0 \%$ \\
\hline Kepuasan & 2 & $4,0 \%$ \\
\hline Kesakitan & 7 & $14,0 \%$ \\
\hline \multicolumn{3}{|l|}{ Umur Responden } \\
\hline$>50$ tahun & 63 & $82,9 \%$ \\
\hline$\leq 50$ tahun & 13 & $17,1 \%$ \\
\hline \multicolumn{3}{|l|}{ Lama menopause } \\
\hline$>5$ Tahun & 47 & $61,8 \%$ \\
\hline$\leq 5$ Tahun & 29 & $38,2 \%$ \\
\hline \multicolumn{3}{|l|}{ Pendidikan } \\
\hline Rendah & 46 & $60,5 \%$ \\
\hline Tinggi & 30 & $39,5 \%$ \\
\hline \multicolumn{3}{|l|}{ Sosial Ekonomi } \\
\hline Rendah ( $\leq$ UMK) & 28 & $36,8 \%$ \\
\hline Tinggi (> UMK) & 48 & $63,2 \%$ \\
\hline \multicolumn{3}{|l|}{ Sumber informasi } \\
\hline Tidak terpapar & 45 & $59,2 \%$ \\
\hline Terpapar & 31 & $40,8 \%$ \\
\hline
\end{tabular}




\section{Status gizi}

Tidak baik (IMT $\leq 18,5-25,0 \mathrm{~kg} / \mathrm{m}^{2}$ dan

$\left.>25,0 \mathrm{~kg} / \mathrm{m}^{2}\right)$

Baik (IMT 18,5-25,0 kg/m²)

Kebiasaan olahraga $\mathbf{R}$

Buruk ( $\leq 3 \mathrm{x}$ dalam 1 minggu selama 30 menit)

Baik (> 3x dalam 1 minggu selama 30

menit)

Riwayat penyakit sistemik

Tidak

Ada
43

33

51

25

43

33
$32,9 \%$

$56,6 \%$

$43,4 \%$

$67,1 \%$

$56,6 \%$

$43,4 \%$
Tabel 1 menunjukkan bahwa mayoritas responden mengalami disfungsi seksual (skor $\leq 26,5)$ sebanyak 50 orang $(65,8 \%)$ dengan domain yang paling banyak pada domain pertama atau hasrat seksual sebanyak 14 orang $(28,0 \%)$. Hal ini dipengaruhi oleh faktor umur responden yang mayoritas > 50 tahun sebanyak 63 orang $(82,9 \%)$, faktor lama menopause responden yang mayoritas sudah > 5 tahun sebanyak 47 orang $(61,8 \%)$, faktor pendidikan responden yang mayoritas rendah (tidak tamat SMA) sebanyak 46 orang (60,5\%), faktor sosial ekonomi responden yang mayoritas rendah $(\leq \mathrm{UMK})$ sebanyak 28 orang $(36,8 \%)$, faktor sumber informasi responden yang mayoritas tidak terpapar informasi mengenai disfungsi seksual pada wanita menopause sebanyak 45 orang (59\%), faktor status gizi responden yang mayoritas tidak baik $\left(\mathrm{IMT} \leq 18,5-25,0 \mathrm{~kg} / \mathrm{m}^{2}\right.$ dan $>25,0$ $\left.\mathrm{kg} / \mathrm{m}^{2}\right)$ sebanyak 51 orang $(67,1 \%)$, faktor kebiasaan olahraga responden yang mayoritas memiliki kebiasaan olahraga yang buruk $(\leq 3 \mathrm{x}$ dalam 1 minggu selama 30 menit) sebanyak 51 orang $(67,1 \%)$ dan faktor riwayat penyakit sistemik responden yang mayoritas tidak memiliki riwayat penyakit sistemik seperti DM, jantung, hipertensi, dan lain - lain sebanyak 43 orang $(56,6 \%)$.

\section{Analisis Bivariat}

Tabel. 2. Prevalensi Disfungsi Seksual berdasarkan Kejadian Disfungsi Seksual

\begin{tabular}{|c|c|c|c|c|c|c|}
\hline \multirow{3}{*}{ Nama Variabel } & \multicolumn{4}{|c|}{ Disfungsi seksual } & \multirow{3}{*}{ OR } & \multirow[t]{3}{*}{$P$ value } \\
\hline & \multicolumn{2}{|c|}{ Disfungsi } & \multicolumn{2}{|c|}{$\begin{array}{l}\text { Tidak } \\
\text { disfungsi }\end{array}$} & & \\
\hline & n & $\%$ & $\mathbf{n}$ & $\%$ & & \\
\hline \multicolumn{7}{|l|}{ Umur } \\
\hline$>50$ tahun & 49 & 77,8 & 14 & 22,2 & \multirow{2}{*}{42,00} & \multirow{2}{*}{0,001} \\
\hline$\leq 50$ tahun & 1 & 7,7 & 12 & 92,3 & & \\
\hline \multicolumn{7}{|c|}{ Lama menopause } \\
\hline$>5$ tahun & 43 & 91,5 & 4 & 8,5 & \multirow{2}{*}{33,79} & \multirow{2}{*}{0,001} \\
\hline$\leq 5$ tahun & 7 & 24,1 & 22 & 75,9 & & \\
\hline \multicolumn{7}{|l|}{ Pendidikan } \\
\hline Rendah & 40 & 87,0 & 6 & 13,0 & \multirow{2}{*}{13,33} & \multirow{2}{*}{0,001} \\
\hline Tinggi & 10 & 33,3 & 20 & 66,7 & & \\
\hline
\end{tabular}




\begin{tabular}{|c|c|c|c|c|c|c|}
\hline $\begin{array}{l}\text { Sosial ekonomi } \\
\text { Rendah (< UMK) }\end{array}$ & 27 & 96,4 & 1 & 3,6 & \multirow{2}{*}{29,35} & 0,001 \\
\hline Tinggi (> UMK) & 23 & 47,9 & 25 & 52,1 & & \\
\hline \multicolumn{7}{|l|}{ Sumber informasi } \\
\hline Tidak terpapar & 39 & 86,7 & 6 & 13,3 & \multirow{2}{*}{11,82} & \multirow{2}{*}{0,001} \\
\hline Terpapar & 11 & 35,5 & 20 & 64,5 & & \\
\hline \multicolumn{7}{|l|}{ Status gizi } \\
\hline $\begin{array}{l}\text { Tidak baik }(\mathrm{IMT} \leq \\
18,5-25,0 \mathrm{~kg} / \mathrm{m}^{2} \text { dan }\end{array}$ & 38 & 88,4 & 5 & 11,6 & \multirow{3}{*}{13,30} & \multirow{3}{*}{0,001} \\
\hline$\left.>25,0 \mathrm{~kg} / \mathrm{m}^{2}\right)$ & & & & & & \\
\hline $\begin{array}{l}\text { Baik (IMT 18,5- } \\
\left.25,0 \mathrm{~kg} / \mathrm{m}^{2}\right)\end{array}$ & 12 & 36,4 & 21 & 63,6 & & \\
\hline \multicolumn{7}{|l|}{ Kebiasaan olahraga } \\
\hline Buruk & 41 & 80,4 & 10 & 19,6 & \multirow{2}{*}{7,29} & \multirow{2}{*}{0,001} \\
\hline Baik & 9 & 36,0 & 16 & 64,0 & & \\
\hline \multicolumn{7}{|l|}{$\begin{array}{l}\text { Riwayat penyakit } \\
\text { sistemik }\end{array}$} \\
\hline Ada & 30 & 90,9 & 3 & 9,1 & \multirow{2}{*}{11,50} & \multirow{2}{*}{0,001} \\
\hline Tidak ada & 20 & 46,5 & 23 & 53,5 & & \\
\hline
\end{tabular}

Tabel 2 menunjukkan bahwa semua variabel independen berhubungan

\section{Analisis Multivariat}

Variabel yang menjadi kandidat dalam model multivariat adalah variabel independen dengan nilai $\mathrm{p}<0,25$. Kemudian dilakukan analisis regresi logistik ganda dengan metode backward, yaitu memasukkan semua variabel independen ke dalam model, tetapi dengan kejadian disfungsi dengan $\mathrm{p}$ value $<0,05$.

kemudian satu per satu variabel independen dikeluarkan dari model berdasarkan kriteria kemaknaan statistik tertentu. Variabel yang dapat masuk dalam model regresi logistik adalah variabel yang mempunyai $p$ - Value < 0,25 pada uji Wald.

Tabel. 3 Model Akhir Analisis Multivariat

\begin{tabular}{llllll}
\hline \multirow{2}{*}{ No } & \multicolumn{1}{c}{ Variabel } & $\begin{array}{c}\text { p- } \\
\text { Value }\end{array}$ & Exp (B) & \multicolumn{2}{c}{$\begin{array}{c}\text { 95.0\% C.I. for } \\
\text { EXP (B) }\end{array}$} \\
\cline { 5 - 6 } & & & Lower & Upper \\
\hline 1. & Lama menopause & .006 & 27.767 & 2.545 & 302.901 \\
2. & Pendidikan & .044 & .067 & .005 & .932 \\
3. & Sumber informasi & .039 & .092 & .010 & .884 \\
4. & Status gizi & .317 & 3.608 & .292 & 44.530 \\
5. & Sosial ekonomi & .180 & 7.408 & .397 & 138.232 \\
6. & Umur & .129 & 15.996 & .445 & 574.661 \\
7. & Kebiasaan Olahraga & .131 & .207 & .027 & 1.598 \\
\hline
\end{tabular}

Tabel 3 menunjukkan bahwa dari hasil analisis bivariat maka variabel dengan $p-$
Value $<0,25$ yang masuk ke dalam model multivariat yaitu umur, lama menopause, 
pendidikan, sosial ekonomi, sumber informasi, status gizi, kebiasaan olahraga dan riwayat penyakit. Kemudian dilakukan analisis regresi logistik ganda dengan metode backward, yaitu memasukkan semua variabel independen ke dalam model, tetapi kemudian satu per satu variabel independen dikeluarkan dari model berdasarkan kriteria kemaknaan statistik tertentu. Variabel yang dapat masuk dalam model regresi logistik adalah variabel yang mempunyai nilai $p-$ Value $<0,05$ pada uji Wald.

Hasil perbandingan OR mengalami perubahan yaitu > $10 \%$ yaitu pada variabel lama menopause dan umur. Dari hasil analisis $\mathrm{p}$ - value yang > 0,05 adalah variabel status gizi, sosial ekonomi, umur dan kebiasaan olahraga. Sedangkan nilai OR yang paling besar adalah variabel lama menopause. Sehingga variabel lama menopause

\section{Daftar Pustaka}

1. Pangkahila, W. Anti - Aging Medicine: Memperlambat Penuaan, Meningkatkan Kualitas Hidup. Jakarta: Kompas Media Nusantara. 2007.

2. Elvira, D. Disfungsi Seksual pada Perempuan. Jakarta: Balai Penerbit FKUI. 2006.

3. Zumantara, A. Disfungsi Seksual. https://www.academia.edu/6533969/ disfungsi_seksual. 2016.

4. Puspayanti. Gara - Gara Seks, Rumah Tangga Berantakan. Th. Puspayanti/tabloid nakita/Rubrik Seksologi/edisi 110/23 April 2001. 2016.

5. Payne, R, E, and Sadovsky, R. Identifying and Treating Premature Ejaculation: Importance of The Sexual History. Cleveland Clinic merupakan faktor yang dominan terhadap kejadian disfungsi seksual pada wanita menopause. Setelah dikontrol oleh 2 variabel diatas, maka dijumpai variabel counfonding dengan $\mathrm{p}$ value $>0,05$ yaitu status gizi, sosial ekonomi, umur dan kebiasaan olahraga.

\section{Kesimpulan}

Angka kejadian disfungsi seksual pada wanita menopause di wilayah kerja puskesmas Tambusai kecamatan Tambusai kabupaten Rokan Hulu Riau tahun 2016 adalah dari 76 responden diantaranya sebanyak 50 orang $(65,8 \%)$ mengalami disfungsi seksual dengan skor < dari 26,5 .

Hasil penelitian menunjukkan semua variabel berhubungan dengan kejadian disfungsi seksual dan variabel dominan adalah lama menopause dengan $\mathrm{OR}=28$.

Journal of Medicine. 74: S47 - S53. 2007.

6. Pangkahila, W. Mitos dan Gangguan Seksual. Kompas Cyber Media .http://64.203.71.11/kesehatan/news/ 0306/25/111235html. 2003.

7. Kavika, P,G. Manajemen Disfungsi Seksual Perempuan. Jakarta: FKUI http:///www.dokumen.tips/document s/1-kayika-manajeman-disfungsiseksual-perempuan-pit-ii-pdui2012dr.html. 2012.

8. Kaplan, Harold dkk. Sinopsis Psikiatri Ilmu Pengetahuan Perilaku Psikiatri Klinis Jilid II Edisi Ketujuh. Jakarta: Bina rupa Aksara. 1997.

9. Palacios, S., Castaño, R., \&Grazziotin, A. Epidemiology of female sexual dysfunction. Maturitas, 63 ,

119-123. 
doi:10.1016/j.maturitas.2009.04.002. 2009.

10. Pangkahila dan Siswanto. Pola Hidup tidak Teratur dan Aktifitas Fisik Berlebihan Menurunkan Kemampuan Aktifitas Seksual. Sport and Journal. 2015.

11. Rosen R, Brown C, Heiman J, Leiblum S, Meston C, Shasigh R. The Female Sexual Function Index (FSFI) .Journal of Sex and Marital Therapy. 26:

191-208.

http://www.fsfiquestionnaire.com/. 2000.

12. Qodriyah, L. Persepsi Ibu Tentang Aktivitas Seksual pada Masa Menopause di Dusun Tegal Sari Desa Jabon Kecamatan Mojoanyar Kabupaten Mojokerto. Skripsi. Mojokerto: Politeknik Kesehatan Mojokerto. 2014.
13. Hastuti L, Hakimi M, Dasuki D. Hubungan antara Kecemasan dengan Aktivitas dan Fungsi Seksual pada Wanita Usia Lanjut di Kabupaten Purworejo. Berita Kedokteran Masyarakat. 2008.

14. Manan E. Bebas dari Ancaman Disfungsi Seksual Khusus Wanita. Jakarta: Buku Biru. 2013.

15. Andini, D. Hubungan Lama Menopause dengan Kejadian Disfungsi Seksual pada Wanita Menopause di Posyandu Lansia Wilayah Kerja Puskesmas Panjang Bandar Lampung. Bandar Lampung: Fakultas Kedokteran Universitas Lampung. 2014.

16. Wahdi. Kadar Estradiol Serum pada Wanita Menopause Dengan Dan Tanpa Syndroma Vasomotor. (Tesis). Universitas Diponegoro. 2003 